\title{
Novel method to achieve crystallinity of calcite by Bacillus subtilis in coupled and non-coupled calcium-carbon sources
}

\author{
Héctor Ferral-Pérez ${ }^{1,2}$, Mónica Galicia-García², Bonifacio Alvarado-Tenorio33, Aldo Izaguirre-Pompa ${ }^{4}$ \\ and Marisela Aguirre-Ramírez ${ }^{1 *}$ (1)
}

\begin{abstract}
Bacteria mineralization is a promising biotechnological approach to apply in biomaterials development. In this investigation, we demonstrate that Bacillus subtilis 168 induces and influences $\mathrm{CaCO}_{3}$ composites precipitation. Crystals were formed in calcium-carbon non-coupled (glycerol $+\mathrm{CaCl}_{2}, \mathrm{GLY}$; or glucose $+\mathrm{CaCl}_{2}, \mathrm{GLC}$ ) and coupled (calcium lactate, LAC; or calcium acetate, ACE) agar-sources, only maintaining the same $\mathrm{Ca}^{2+}$ concentration. The mineralized colonies showed variations in morphology, size, and crystallinity form properties. The crystals presented spherulitic growth in all conditions, and botryoidal shapes in GLC one. Birefringence and diffraction patterns confirmed that all biogenic carbonate crystals (BCC) were organized as calcite. The $\mathrm{CaCO}_{3}$ in $\mathrm{BCC}$ was organized as calcite, amorphous calcium carbon (ACC) and organic matter (OM) of biofilm; all of them with relative abundance related to bacteria growth condition. BCC-GLY presented greatest OM composition, while BCC-ACE highest $\mathrm{CaCO}_{3}$ content. Nucleation mechanism and OM content impacted in BCC crystallinity.
\end{abstract}

Keywords: Bacillus subtilis organomineralization, Biogenic calcite, Calcium carbonate composites, Micrite

\section{Key points}

- B. subtilis mineralized colonies show spherulitic and botryoidal growth.

- BCC are mainly composed for calcite, ACC and $\mathrm{CaCO}_{3}$ precipitant wrapped up in EPS.

- Crystalitte is evident in non-coupled calcium-carbon sources conditions.
*Correspondence: marisela.aguirre@uacj.mx

1 Laboratorio de Biología Celular y Molecular, Departamento de Ciencias

Químico-Biológicas, Instituto de Ciencias Biomédicas, Universidad

Autónoma de Ciudad Juárez, 32310 Cd. Juárez, CHIH, Mexico

Full list of author information is available at the end of the article

\section{Introduction}

Bacterial $\mathrm{CaCO}_{3}$ mineralization is a phenomenon that occurs in sediments, caves, hot springs, soils and even in monuments and buildings (Ciferri et al. 2000; Rusznyák et al. 2012; Páramo et al. 2015). In nature, calcium carbonate biomineralization occurred in three different pathways: (i) controlled biological mineralization (CBM), (ii) induced biological mineralization (INDBM) and (iii) influenced biological mineralization (INFBM) (Dove et al. 2003). In CBM, organisms produce ordered mineral structures by a specified enzymatic mechanism encoded in their genes (Ngwenya 2016). Moreover, INDBM and INFBM are passive mechanisms, where physiological activity induces spontaneous precipitation of ions (Knorre and Krumbein 2000) or mineralization are influenced by extracellular polymeric substances (EPS) and biofilm geometry (Dupraz et al. 2009), respectively. $\mathrm{CaCO}_{3}$ precipitation is strongly influenced by basically four conditions: high $\mathrm{pH}$ environment $\left(\mathrm{pK}_{2}[\mathrm{CO}]=10.3\right.$ 
at $25{ }^{\circ} \mathrm{C}$ ), oversaturation of $\mathrm{Ca}^{2+}$ and $\mathrm{CO}_{3}{ }^{2-}$, and availability of nucleation sites (Dupraz et al. 2009).

It has been demonstrated the occurrence of B. subtilis culture alkalinization in rich media (Robinson et al. 1991) probably due to spontaneous extracellular proteins, or amino acids deamination (Dupraz et al. 2009). Besides, when cells oxidate the carbon sources, the resulting product comprises $\mathrm{CO}_{2}$ and water. Under alkaline conditions, $\mathrm{CO}_{2}\left(\mathrm{pK}_{2}[\mathrm{CO}]=10.3\right.$ at $\left.25^{\circ} \mathrm{C}\right)$ spontaneously evolve into $\mathrm{CO}_{3}{ }^{2-}$ (Stumm 1990). In addition, some Bacillus species could accelerate the hydration of $\mathrm{CO}_{2}(\mathrm{~g})$ through carbonic anhydrase activity (Dhami et al. 2014).

Additionally, calcium uptake and extrusion in bacteria are passive processes promoted by osmotic forces across a $\mathrm{Ca}^{2+} / \mathrm{H}^{+}$antiporter protein. Besides, there is a $\mathrm{Ca}^{+2} /$ $\mathrm{Na}^{+}$antiporter pump that also maintains low intracellular calcium concentration (De Vrij et al. 1985) and, creates a high saturated microenvironment near to cell wall and EPS (Banks et al. 2010; Perito and Mastromei 2011; Meier et al. 2017).

Finally, B. subtilis produced $\mathrm{CaCO}_{3}$ minerals by INFBM; where EPS, membrane, and cell wall structures act as nucleation sites (Perito et al. 2014; Priya et al. 2016). Specifically, the metabolism of fatty acids plays a key role in biomineralization process (Perito et al. 2000; Barabesi et al. 2007), such as dipicolinic acid (Marvasi et al. 2017).

In vitro, B. subtilis promotes calcite crystals formation in presence of different calcium sources such as calcium lactate (Sierra-Beltran et al. 2014), calcium acetate (Shirakawa et al. 2011) or calcium chloride (Shirakawa et al. 2011; Micallef et al. 2016). In most of those cases, the addition of urea to promote $\mathrm{pH}$ increase is recurrent. Nevertheless, a recent work shows that non-ureolityc Bacillus strains that precipitates calcite could be used to mortar healing (Reeksting et al. 2020).

In order to propose an alternative white biotechnology method, this research demonstrated that $B$. subtilis facilitates $\mathrm{CaCO}_{3}$ precipitation through non-ureolytic pathway. As well, the acquiring of different crystallinity biogenic calcite could be achieved using either coupled or non-coupled calcium-carbon sources.

\section{Materials and methods}

Calcium carbonate biogenic crystal production and recovery

Bacillus subtilis 168 (ATCC ${ }^{\circledR} 27370^{\mathrm{TM}}$ ) strain was used in this work. Bacteria pre-culture was propagated in Nutrient broth (BD Bioxon, Cuatitlán Izcalli, México) by $24 \mathrm{~h}$, at $37^{\circ} \mathrm{C}$. Petri dishes with of four different agar composition were inoculated with $1.17 \times 10^{7}$ cells $\mathrm{mL}^{-1}$. The plates were incubated at $37{ }^{\circ} \mathrm{C}$ for 9 days. Nutrient Agar (BD Bioxon, Cuatitlán Izcalli, México) medium was supplemented with $0.026 \mathrm{M}$ glycerol (Bio Basic, San Nicolas de la Garza, México) +0.1 $\mathrm{M} \mathrm{CaCl}_{2}$ (GLY), $0.013 \mathrm{M}$ glucose (HYCEL, Zapopan, México) + $0.1 \mathrm{M}$ $\mathrm{CaCl}_{2}$ (Jalmek, San Nicolás de la Garza, México) (GLC), 0.1 M calcium lactate (Cosmopólita, Naucalpan de Juárez, México) (LAC) or $0.1 \mathrm{M}$ calcium acetate (LABESSA, Ciudad de México, México) (ACE). Bacteria growth modified $\mathrm{pH}$ values in liquid Nutrient Broth in all supplemented conditions. Initial $\mathrm{pH}$ varied between 6.5 and 7.1, and after eight hours, it increased until 9.3 as expected (Additional file 1: Fig. S1).

After incubation time, to detach the mineralized colonies from agar, culture was washed (López-Moreno et al. 2014) with $5 \mathrm{~mL}$ of boiling water, for calcium acetate and calcium lactate media, 2-3 washes were needed and for glucose and glycerol 4-6 washes were need because the producer amount of EPS. The water was recovered in a clean recipient to allow crystals sedimentation by $10 \mathrm{~min}$. The crystals were washed with boiling water until the supernatant became clear. To eliminate the excess of organic residuals, sediment was washed several times with 1:3 acetone-alcohol (HYCEL, Zapopan, México) solution in vortex by $10 \mathrm{~s}$, until supernatant became clear. The supernatant was thrown out and crystals were oven at $80^{\circ} \mathrm{C}$ for $12 \mathrm{~h}$ to evaporate the rest of water and solvent.

\section{Petrographic analysis}

A petrographic analysis was performed to internally characterize the crystals using polarizing microscopy. Standard petrographic thin section procedures (Murphy 1986) were modified to perform thin section of one fraction of BCC powder and flake aggregates. BCC were encapsulated into clear epoxy resin (COMEX, Mexico City, México) on the flat surface of a standard slide glass $(26 \times 46 \mathrm{~mm})$. After curing epoxy resin, were trimmed and grinded until reach $100 \mu \mathrm{m}$ thickness employing a saw/grinder machine (Ingram Thin Section Model 65). Encapsulated samples were finished by hand using silicon carbide and alumina abrasives in order to get $\sim 25 \mu \mathrm{m}$ of thickness and a polished surface. Thin sections were observed in Leica Petrographic Microscope DM2700 P with cross Nicols. The integrity of all samples was first evaluated in bright field (e.g. Additional file 1: Fig. S2).

\section{SEM analysis}

Other fraction of $\mathrm{BCC}$ was sputtered with $\mathrm{Pt} / \mathrm{Ag}$ layer by cathodic sputtering (MNT-JS1600, Micronano Tools) during 1 min (Folk and Lynch 1997). BCC were observed by scanning electron microscopy (SEM) in a JEOL JSM7000F field emission scanning electron microscope. To determinate crystals elemental composition, energy dispersive $\mathrm{x}$-ray spectroscopy (EDX) were performed. 


\section{XRD analysis}

Polymorphism and crystalline structures were determined by X-ray diffraction (XRD) using powder diffraction data method (Kontoyannis and Vagenas 2000). Panalytical X'pert Pro X-Ray MRD diffractometer was used; the X-ray emission was produced by copper cathode at $K \alpha 1=1.5405 \AA$ wavelength and 20 to $802 \theta$ degrees by 0.001 step protocol. The diffractograms were analyzed by means of the MATCH software.

\section{Crystallite size and crystallinity index determination}

The theoretical crystallite size $(\tau)$ was calculated using the Scherrer equation (Patterson 1939; Eq. 1), using 0.9 as shape factor $(K)$, the specific wavelength $(\lambda)$ provide by the XRD equipment, the line broadening half the maximum intensity $(\beta)$ and the Bragg angle $(\theta)$ of the more intense plane of the calcite (104) (Person et al. 1995; Merino and Morales 2008).

$$
\tau=\frac{K \lambda}{\beta \cos \theta}
$$

Likewise, the area of the most intense peak (104) was determined, and compared with respect to mineral calcite, which has a crystallinity index (CI) of $99 \%$. The area of (104), (006), (110) and (113) peak was calculated in order to calculate the crystalline index (IC; Eq. 2).

$$
I C=\frac{\sum \text { Area of peaks pattern }}{\sum \text { Area of peaks sample }}
$$

\section{ATR-FTIR analysis}

The crystalline and amorphous phases composition was performed by Fourier Transformed Infra-Red spectrometry (ATR-FTIR). Crystals were analyzed in Bruker Alfa Platino-ATR spectrophotometer from 4000 to $400 \mathrm{~nm}$.

\section{Thermal stability}

To analyze crystal composition and thermal stability, $5 \mathrm{mg}$ of biogenic crystals were compacted in aluminum pans. An SDT Q600 TA equipment was used for thermogravimetric analysis, temperature range was from 35 to $850{ }^{\circ} \mathrm{C}$, heating rate was $10{ }^{\circ} \mathrm{C} \mathrm{min}-1$, working atmosphere was air at $50 \mathrm{~mL} \mathrm{~min}{ }^{-1}$ of gas flow.

\section{Results}

\section{Composites biomineralization}

After 9 days of incubation at $37^{\circ} \mathrm{C}$, B. subtilis mineralized colonies were harvested from Petri dishes with nutrient agar supplemented with glycerol $+\mathrm{CaCl}_{2}$ (GLY), glucose $+\mathrm{CaCl}_{2}$ (GLC), calcium lactate (LAC) or calcium acetate (ACE). Colonies formed in GLY and GLC (Fig. 1a, b) were scattered distributed over the plate comparatively of LAC or ACE (Fig. 1c, d) conditions. Once the material was detached with hot water $\left(\sim 90{ }^{\circ} \mathrm{C}\right)$, washed and cleaned up from non-mineralized cells and EPS, it was observed at metallographic microscope.

The bigger confluent colonies were obtained in both non-coupled conditions (GLY and GLC), but with irregular forms in GLY (Fig. 1a) than GLC (Fig. 1b); these were orange pigmented too. Coupled conditions showed smaller mineralized colonies, with typical smooth and regular borders; where the saturation of Petri dish was predominantly in ACE condition (Fig. 1d).

\section{Internal structures of biogenic calcium carbonate crystals}

A petrographic study was performed in mineralized colonies of B. subtilis grown on different media (Fig. 2). The mineral shape, size composite, internal structure, and optical properties were shown in polarizing and analyzed light, where the black background (epoxy resin, Additional file 1: Fig. S2) is surrounding Biogenic Carbonate Crystals (BCC) in bright colors. In GLY condition (Fig. 2a), BBC shown the most amorphous growth habit. All BCC shown at least three interference colors of $4^{\text {th }}$ order in Michel-Lévy scale with wedge-shaped margin, suggesting calcite presence. Moreover, in BCCLAC and BCC-ACE (Fig. 2c, d), it is clear light extinction North-South/Este-West between microscope polarizing axes and mineral axes (Maltese cross), which fits to fiberradial crystal distribution. BCC-GLC (Fig. 2b) exhibited a better spherical and bigger size composite $(\sim 300 \mu \mathrm{m}$ of diameter). Nevertheless, also it can be overbed ring growths of smaller crystals. In all conditions, BCC apparently grown in a layered crystal arrange, although in BCC-GLY (Fig. 2a) mineral layer seems do not have an order in comparison to other obtained crystals. BCCGLC (Fig. 2b) have a crystal layers starting in several nuclei all over the colony. It can be observed as changes in color separated by color lines. However, for BCC-LAC (Fig. 2c) and BCC-ACE (Fig. 2d), layers start from top to the bottom layer, in that order until forms the crystal. Finally, micrite present botryoidal growth with nodular arrangement in BCC-GLC (Fig. 2b and Additional file 1: Fig. S3).

\section{BCC crystalline properties}

To determine the crystallographic properties of the $\mathrm{BCC}$ produced, the samples were subjected to X-ray diffraction by powder method. Calcite was the only $\mathrm{CaCO}_{3}$ polymorphism obtained in $\mathrm{BCC}$ of each condition (Fig. 3a), as was inferred from the intensity of 104 surface plane. The BCC-GLC shown the highest crystallinity (85\%), 

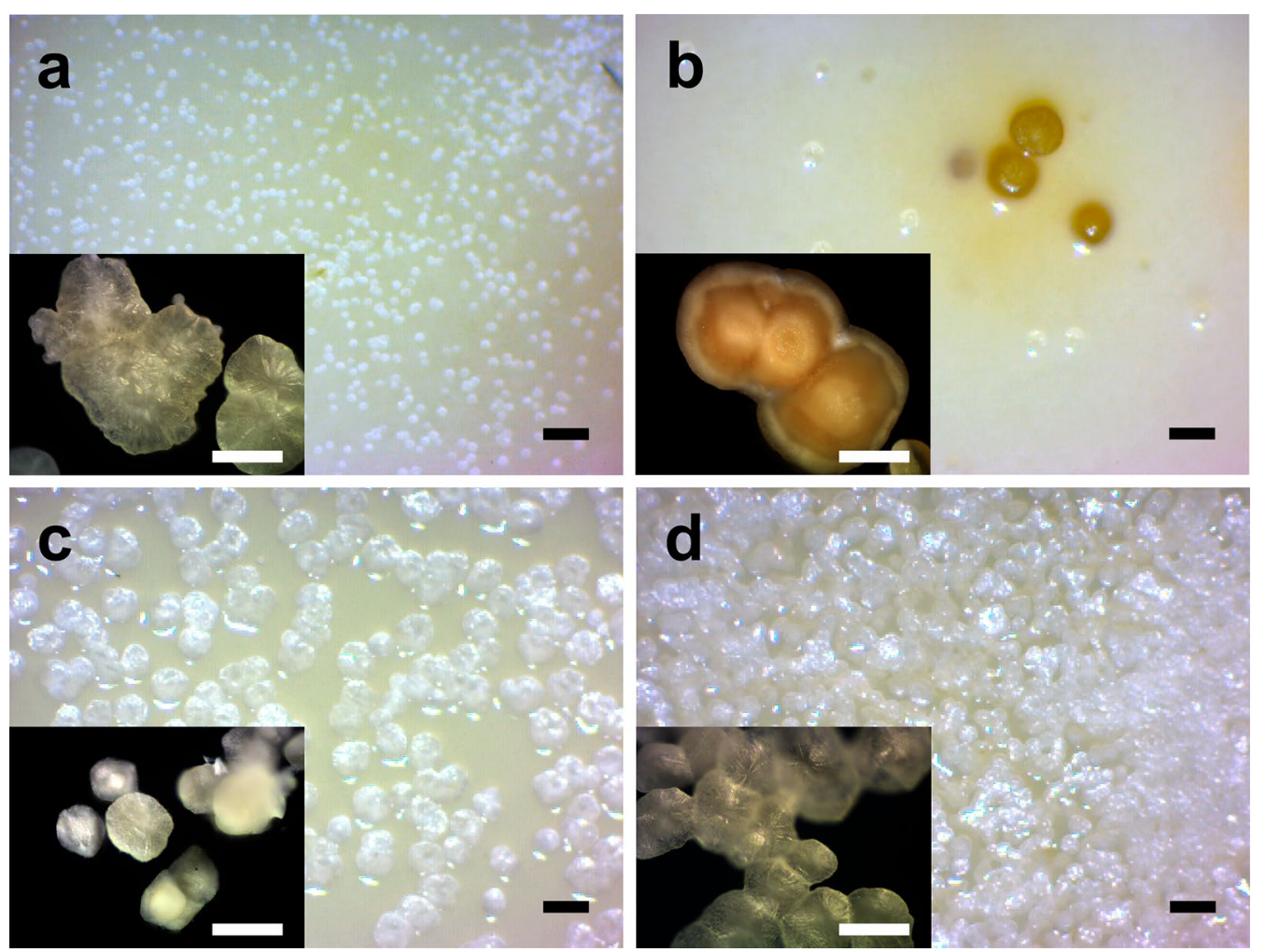

Fig. 1 Cultures of B. subtilis and mineralized cell colonies formed in coupled and non-coupled calcium-carbon sources media. Images show stereoscopic view of plates and metallographic micrographs of recovered composites from a GLY, b GLC, c LAC, and $\mathbf{d}$ ACE media. Scale bars: 1 mm (black); $100 \mu \mathrm{m}$ (white)

followed by BCC-ACE (80\%), BCC-LAC (56.7\%) and BCC-GLY (53.4\%) (Fig. 3b). The crystallite size interval for all $\mathrm{BCC}$ was between 30 and $60 \mathrm{~nm}$, where the largest and smallest one was obtained in BCC-GLC and BCCLAC, respectively.

\section{Crystalline structures and superficial morphology of BCC}

The BCC morphology was analyzed by SEM. BCC aggregates sizes varied in the four growth conditions as follow: 33-217 $\mu \mathrm{m}$ of BCC-GLY; 43-316 $\mu \mathrm{m}$ of BCC-GLC; $48-118 \mu \mathrm{m}$ of BCC-LAC and 38-172 $\mu \mathrm{m}$ of BCC-ACE.

$\mathrm{BCC}$ presented different mineralized structures, such as scales (Fig. 4a) or rhombohedral irregular shapes (Fig. 4c) formed in uncouple and couple calcium-carbon sources, respectively. Those structures correspond to calcite morphology. The mineralized EPS were more evident in BCC-GLY and BCC-GLC (Fig. 4b) than BCC-LAC or BCC-ACE. Crystallite formations were evident just in non-coupled sources (Fig. 4a, b and Additional file 1: Fig. S4a, b); their sizes are in concordance to XRD data (Fig. 3b). In all condition cells were mineralized, INDBM was evident in coupled calcium-carbon sources, where rhombohedral shapes occurred in cell wall (Fig. 4d).
The mineralized cells were also observed inside colonies formed in ACE condition (Additional file 1: Fig. S5). As well, other ultra-structures were observed between mineralized cells, like fibers growing in nets $(0.5 \mu \mathrm{m})$ between foliated scales and mineralized EPS of BCC-GLC (Fig. 5a) or forming bridges $(10 \mu \mathrm{m})$ between colonies in $\mathrm{BCC}$ LAC (Fig. 5a).

\section{BCC composition analysis}

The thermogravimetric analysis (TGA) of BCC showed similar patterns in all four conditions (Fig. 6). They presented three important mass lost (Fig. 6a) at $75{ }^{\circ} \mathrm{C}$ and $237{ }^{\circ} \mathrm{C}$ and between 700 and $800{ }^{\circ} \mathrm{C}$. These changes are more pronounced in BCC-GLY. The first one could be associate to dehydration of amorphous $\mathrm{CaCO}_{3}$. Second one corresponds to organic matter loss, where BCC-GLY reduced its mass 22\%, BCC-LAC 6.5\%, BCC-GLC 5.5\%, and BCC-ACE 5\%. The last process belongs to $\mathrm{CaCO}_{3}$ decomposition to $\mathrm{CaO}$ on $\mathrm{BCC}$, where in $\mathrm{BCC}-\mathrm{GLC}$, BCC-LAC and BCC-ACE the lost occurred between 38.3 and $40.4 \%$. While in BCC-GLY weight lost was $28.8 \%$. These thermic BCC processes (Fig. $6 \mathrm{~b}$ ) could be described as: endothermic one near $100{ }^{\circ} \mathrm{C}$, followed by 

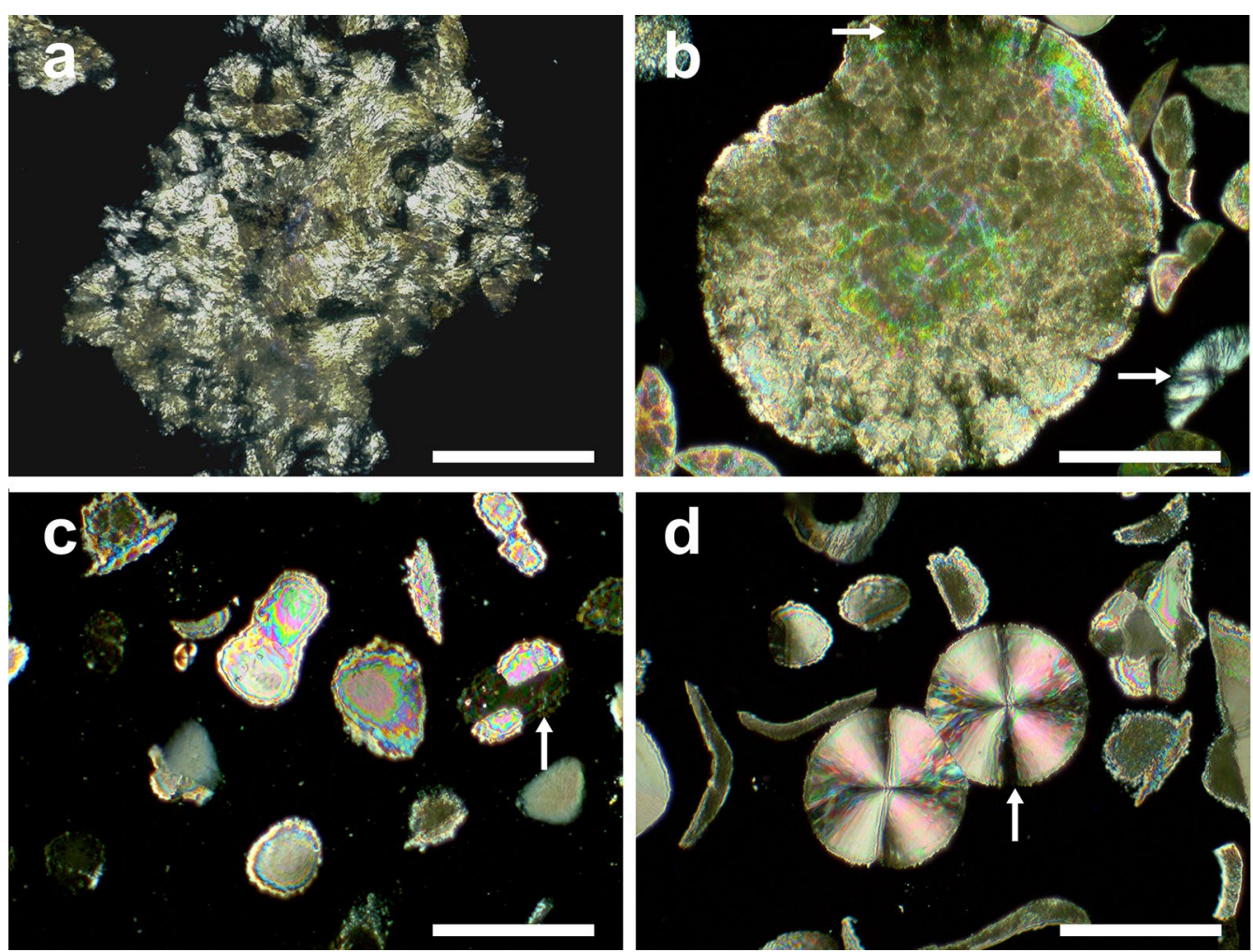

Fig. 2 Thin section micrographs of mineral grow composites produced in presence of Bacillus subtilis at different condition. a BCC-GLY, b BCC-GLC, c BCC-LAC, and $\mathbf{d}$ BCC-ACE. Images were acquired with polarized and analyzed light. They show size, shape, and optical properties of biogenetic crystals from diverse media. Arrows symbol show a key optical property, of light extinction (see result and discussion text). Scale bar: $100 \mu \mathrm{m}$

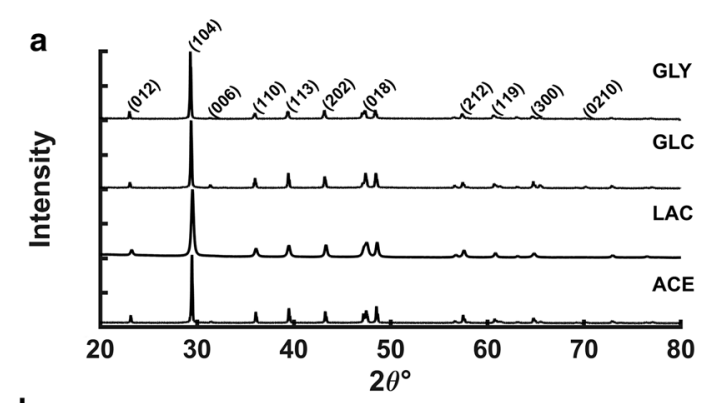

b

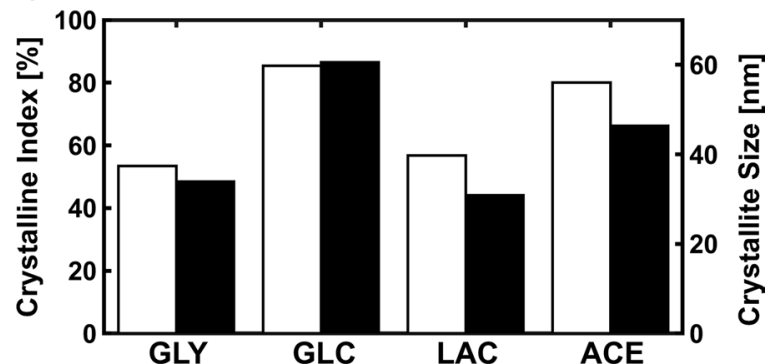

Fig. 3 Crystallographic properties of BCC. Diffractogram a of BCC-GLY, BCC-GLC, BCC-LAC and BCC-ACE. b Bars show the crystallinity index (white, left scale) and crystallite size of 104 peak (black, right scale) of composites obtained in each condition exothermic one between 335 and $340{ }^{\circ} \mathrm{C}$, and two endothermic process at $535{ }^{\circ} \mathrm{C}$ and between 728 and $802{ }^{\circ} \mathrm{C}$. The changes in heat flow during thermal decomposition (Fig. 6c) were measured by enthalpy $(\Delta \mathrm{H})$. In $331-338^{\circ} \mathrm{C}$ the values were $430.96,480.73,579.69,10,497 \mathrm{~J} \mathrm{~g}^{-1}$ ${ }^{\circ} \mathrm{C}^{-1}$, with peak temperature in $332,350,347.5$ and $349^{\circ} \mathrm{C}$ for BCC-ACE, BCC-LCA, BCC-GLC, and BCCGLY, respectively. In $744-800{ }^{\circ} \mathrm{C}$ the reported values were 1149.6, 1758.8, 2275.6, 4487.5 $\mathrm{J} \mathrm{g}^{-1}{ }^{\circ} \mathrm{C}^{-1}$ at 744.38, $745.74,755.64,799.99^{\circ} \mathrm{C}$ for BCC-GLY, BCC-GLC, BCC$\mathrm{LAC}$, and BCC-ACE, respectively. The BCC with better and worst thermal stability were obtained in ACE and GLY media, respectively. All data above indicate the presence of higher organic matter in BCC-GLY.

Additionally, EDX analysis of $\mathrm{BCC}$ surfaces showed that all composites were mainly formed by $\mathrm{C}, \mathrm{O}, \mathrm{Ca}$ and, in lower proportion by $\mathrm{N}, \mathrm{P}$, and $\mathrm{S}$ (Additional file 1: Fig. S6a). Besides, all BCC were evaluated by FTIR-ATR spectrophotometry in the near infrared spectrum. The absorption bans of $\mathrm{CO}_{3}{ }^{2-}$-calcite vibrational groups were observed (Additional file 1: Fig. S6b), such as $v_{4 s} \mathrm{CO}_{3}$, at $712 \mathrm{~cm}^{-1}, v_{2 \mathrm{as}} \mathrm{CO}_{3}$ at $870 \mathrm{~cm}^{-1}$ and $v_{3 \mathrm{as}} \mathrm{CO}_{3}$ at $1409 \mathrm{~cm}^{-1}$ (Plav et al. 1999). Moreover, the presence of functional 

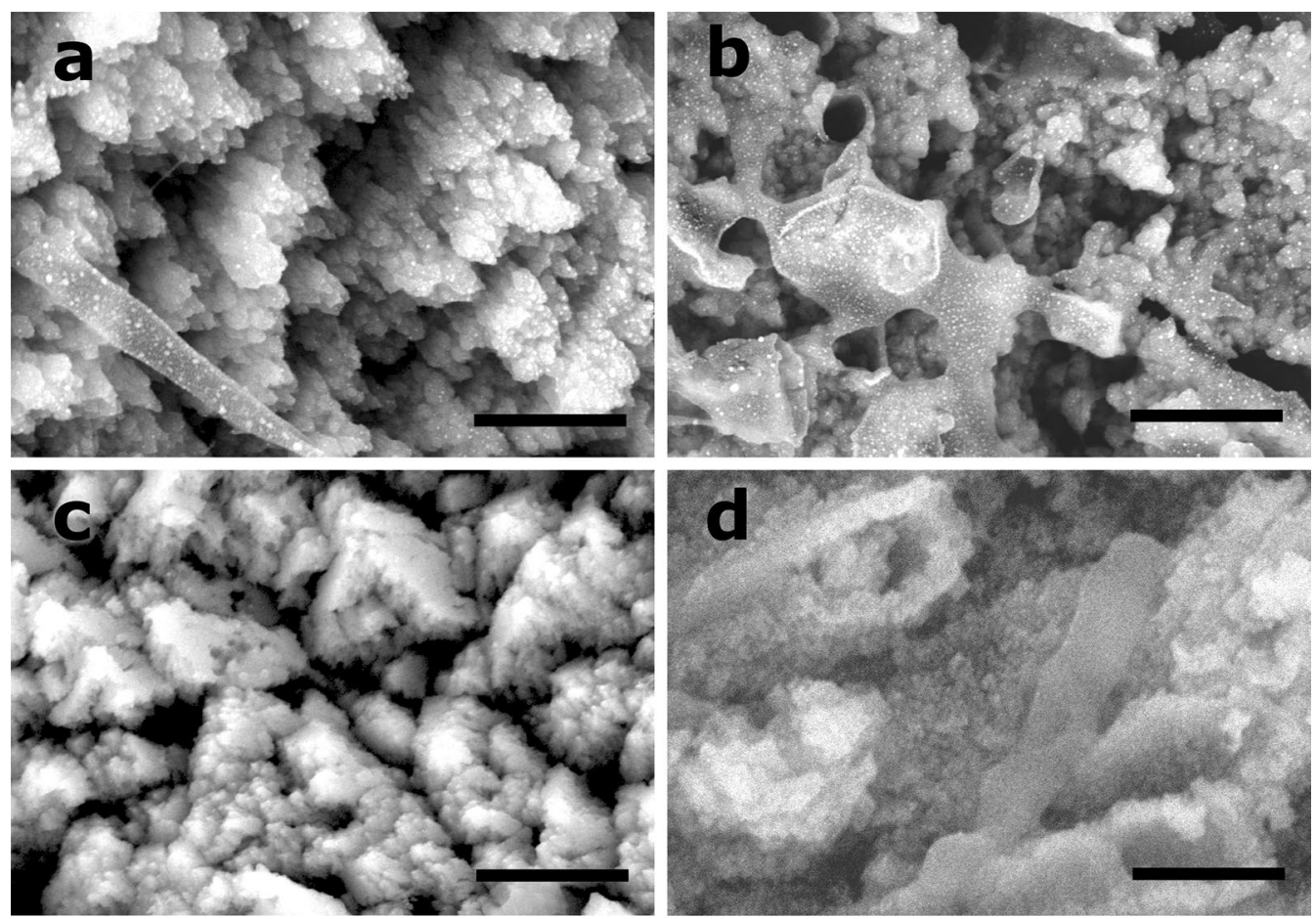

Fig. 4 BCC structures formed in non-coupled and coupled calcium-carbon sources. SEM images of BCC-GLC (a, $\mathbf{c})$ and BCC-ACE (c, d) are shown. Scales (a) and rhombohedral calcite irregular shapes (c) are present. Crystallites grow over calcite aggregates and mineralized EPS in non-coupled sources $(\mathbf{a}, \mathbf{b})$. Besides, induced mineralization occurs over the cell wall in coupled source $(\mathbf{d})$. Scale bars: $1 \mu \mathrm{m}$.
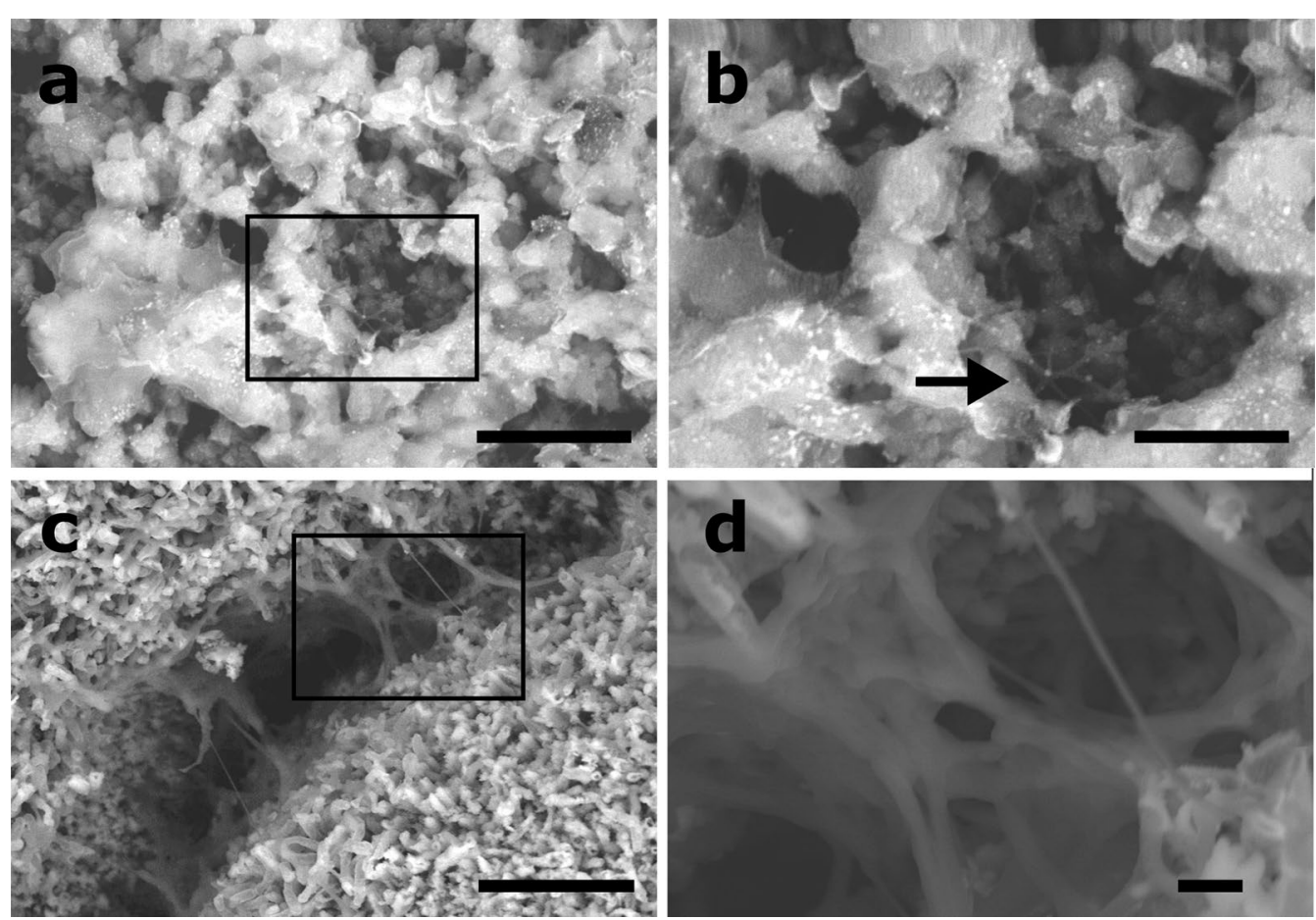

Fig. 5 Mineralized micro and nanofibers of BCC-EPS. SEM images of a BBC-GLC and $\mathbf{c} B C C-L A C$ are shown. The rectangles (b, d) indicate its respective magnifications, and nanofibers are pointed out (black arrow). Scale bars: $10 \mu \mathrm{m}(\mathbf{a})$ and $1 \mu \mathrm{m}(\mathbf{b})$, and $1 \mu \mathrm{m}(\mathbf{c})$ and $0.5 \mu \mathrm{m}(\mathbf{d})$ 

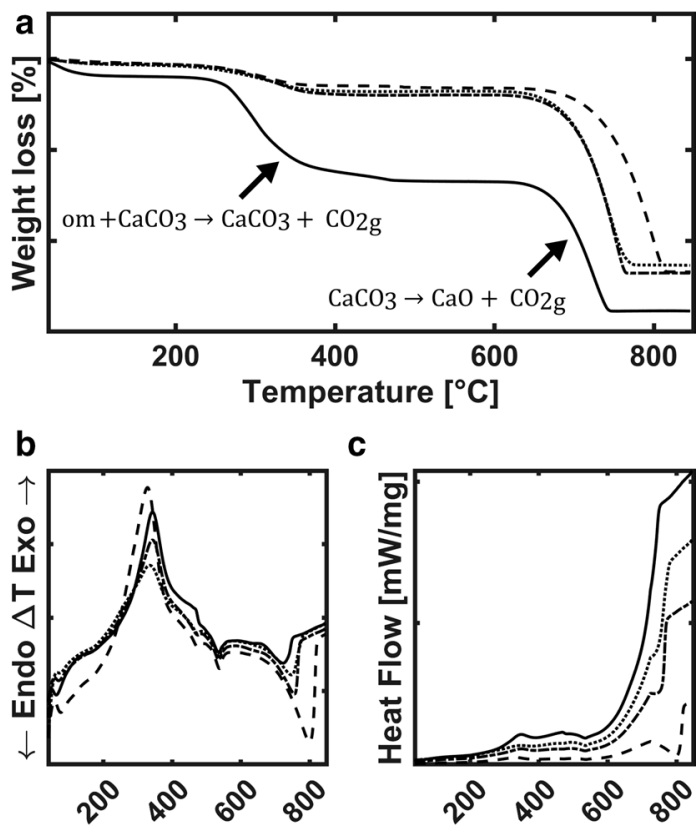

Temperature $\left[{ }^{\circ} \mathrm{C}\right]$

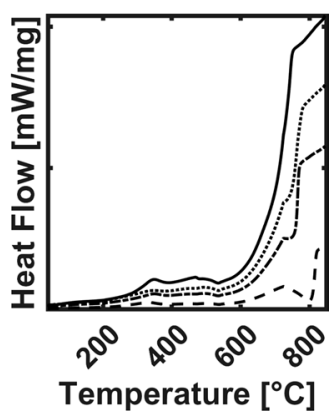

Fig. 6 Phase transition of composites formed on different media. a Thermogravimetric (TGA) profile and material weight loss of organic matrix (om), carbon dioxide $\left(\mathrm{CO}_{2}\right)$ and calcium oxide $(\mathrm{CaO})$. b Differential thermal analysis and $\mathbf{c}$ differentia scanning calorimetry (DSC) show degradation enthalpy and crystalline transition of amorphous calcium carbonate (ACC) to crystalline $\mathrm{CaCO}_{3}$. Lines indicate BCC-GLY (solid), BCC-GLC (dot), BCC-LAC (grid), and BCC-ACE (dashed)

groups of organic origin was found, such as $v_{\mathrm{s} 3} \mathrm{PO}_{4}$ at $580 \mathrm{~cm}^{-1}$ and $v$ COP at $1145 \mathrm{~cm}^{-1}$; narrowing of $-\mathrm{C}-\mathrm{O}-$ $\mathrm{C}-$ and $\mathrm{C}-\mathrm{O}$ related to polysaccharides between 1000 and $1154 \mathrm{~cm}^{-1}$; amide and amino groups as $v \mathrm{sH}_{2}$ at $1623 \mathrm{~cm}^{-1} ; v_{\mathrm{s}} \mathrm{CO}$ at $1653 \mathrm{~cm}^{-1} ; v_{\mathrm{s}} \mathrm{CO}^{\text {free }}$ at $1682 \mathrm{~cm}^{-1}$; $\delta \mathrm{NH}$ at $776 \mathrm{~cm}^{-1}$ an sulfur group as $v_{\text {as }} \mathrm{SO}$ at $1390 \mathrm{~cm}^{-1}$. After $1800 \mathrm{~cm}^{-1}$, no signal of a functional group was observed.

\section{Discussion}

The BCC produced in presence of B. subtilis had different morphological and crystallographic properties, depending of media composition: (a) conditions where the calcium source is not associated to carbon one, non-coupled (GYL and GLC); or (b) where the calcium is attached to the carbon source, coupled (LAC and ACE). The predominant morphologies in petri dish were mineralized colonies with rounded shape and convex (Fig. 1), in contrast to experiments done in liquid media were dumbbell, rhombohedral and spherulitic shapes are common (Han et al. 2019). Independently to media, the main factor that induced carbonate precipitation is the microenvironment alkalinization, that enhance complexation of $\mathrm{Ca}^{2+}$ free ions with free $\mathrm{CO}_{3}{ }^{2-}$ ion (Dupraz et al. 2009). Specifically, in nutrient media, glutamine deamination (Dervaux et al. 2014), and carbonic anhydrase activity (Frankel and Bazylinski 2003; Perito and Mastromei 2011; Oppenheimer-Shaanan et al. 2016; Han et al. 2019) could provoke this $\mathrm{pH}$ changes (Jiménez-Delgadillo et al. 2018). $\mathrm{pH}$ changes in long term Bacillus culture in agar-rich media (Robinson et al. 1991).

Only BCC-GLC were orange pigmented (Fig. 1b), which is related to iron chelation by pulcherriminic acid produced in biofilms of carbohydrates supplemented media (Arnaouteli et al. 2019).

Thin section micrography show birefringence phenomena under polarized light (Fig. 2). However, due the presence of optical interference color of light greenextinction characteristic 4th order birefringence it can be interrelated has arrangement of typical calcite carbonate crystals (Aizenberg and Hendler 2004). However, did not show the characteristic calcite cleavage. Difference in the interference color in crystals indicates a non-oriented arrangement of microcrystal growth, it can be produced by the randomized growth of bacteria colonies. However, mineral growth in glycerol media is also determined by crystal nucleation in EPS produced by cells (Oppenheimer-Shaanan et al. 2016), that is probably the cause of its amorphous habit. Micrite is common in marine sediments and microbialites (Perri and Spadafora 2011) with spherical and radial-fibers growth as we observed in all BCC; mineralized cells are also present (Rasmussen and Muhling 2019).

Several strains of Bacillus could mineralize different polymorphisms of $\mathrm{CaCO}_{3}$, such calcite and vaterite (Seifan et al. 2016; Andrei et al. 2017; Huynh et al. 2018), but factors that induce only one kind of polymorphism are not jet understood. In this work well only observe calcite production, even if calcium-carbon source was non-coupled. Other authors have identified this crystalline phase in B. subtilis (Zhuang et al. 2018; Han et al. 2019). The obtained BCC had different crystallinity (BCC-GLY $<$ BCC-ACE $<$ BCC-LAC $<$ BCCGLC), possibly related to mineralization process in each formation-condition (Fig. 3b). The IC of BCC-GLC may be similar to abiotic process $\mathrm{pH}, \mathrm{Ca}^{2+}$ concentration and nucleation sites are critical (Perito and Mastromei 2011). For coupled calcium-carbon sources, like ACE (Fig. 4d, Additional file 1: Figure S5), the mineralization mainly occurred over cellular structures such as cell wall and EPS (Marvasi et al. 2012; Dhami et al. 2013). In that sources, critical $\mathrm{Ca}^{2+}$ concentration could be accumulated in cell wall because the efflux pump and specific channels (Saier et al. 2002). The membrane and cell wall components could be nucleation sites because 
its negative charges of teichoic acid that attract $\mathrm{Ca}^{2+}$ (Perito et al. 2014).

Lower IC in BCC-LAC and BCC-GLY could be associated to higher production of organic matter or amorphous calcium carbonate (ACC). This is the polymorphic precursor of crystalline structures under biotic or abiotic mineralization (Bots et al. 2012; Cantaert et al. 2016). Some interaction with glycoproteins or organic molecules increased the ACC stability and prevent spontaneous crystallization (Aizenberg et al. 2002; Weiner et al. 2003). Additionally, in non-coupled calcium-carbon sources (GLY and GLC), BCC nanodeposits with the same sizes of calculate crystallite were evident over calcite scales and mineralized EPS (Fig. 4a, b, Additional file 1: Fig. S4). This is the first work where such kind of precipitants are observed in biocomposites of B. subtilis.

The main components of B. subtilis EPS, that promote calcite aggregation, are TasA and TapA amyloid proteins and exopolysaccharides (Azulay and Chai 2019); moreover, there are reports of nanotubes formation when $B$. subtilis grows in rich media (Bhattacharya et al. 2019). In this study, both structures were observed in BCC-GLC (Fig. 5b) and BCC-LAC (Fig. 5c), respectively.

In order to understand the $\mathrm{BCC}$ composition, TGA and DSC analysis were performed (Fig. 6). Thermic change of biotic and abiotic vaterite was reported with an exothermic peak between 317 and $318{ }^{\circ} \mathrm{C}$, that was associated to organic matter decomposition with $\mathrm{CO}_{2}$ and $\mathrm{NO}_{2}$ release (Rodriguez-Navarro et al. 2007). Furthermore, at $700-800{ }^{\circ} \mathrm{C}$ a second reaction occurs, from $\mathrm{CaCO}_{3}$ to $\mathrm{CaO}$ (Al Omari et al. 2016). As we saw, BCC-GLY presented greater abundance of organic matrix; however, temperature decomposition not follow enthalpy rise. Some organic acids could change temperature peaks of that process (Li et al. 2017).

Mineralization degree (BCC-ACE $>$ BCC-LAC $>$ BCCGLC > BCC-GLY) also affected thermic stability of BCC in relation to enthalpy and decomposition temperatures (Fig. 6). This may be to mineral abundance or lattice variation (Pokroy et al. 2006), such as in BCC-GLC with higher crystallinity but low presence of $\mathrm{CaCO}_{3}$.

In BCC, EPS could increase complexation by the interaction of the ions with the electronegativity charge of its expose functional groups (Ercole et al. 2007; Oppenheimer-Shaanan et al. 2016). This explain the random nucleation of minerals that occurs in the bacteria microenvironment. However, in BCC-GLY the synthesis level of EPS increases the amount of nucleation sites but affected negatively the crystallinity. EPS have a key role in $\mathrm{CaCO}_{3}$ precipitation (Arias and Fernández 2008 ), and B. subtilis produce high amount of different types in glycerol supplemented media (Oppenheimer-Shaanan et al. 2016). Besides, EPS is important to
$\mathrm{CaCO}_{3}$ precipitation (Decho 2010; López-Moreno et al. 2014), because it attract $\mathrm{Ca}^{2+}$ to its chemical functional groups, such as: $\mathrm{COO}-, \mathrm{NH}_{3}-, \mathrm{PO}_{4}-$ and $\mathrm{SO}_{4}-$ groups (Schmitt and Flemming 1998; Humbert and Quilès 2011). Those group, related to main EPS components (exopolysaccharides and proteins) play a key role in BCC formation (Azulay and Chai 2019). P content may be related to extracellular DNA usually present in EPS (Peng et al. 2020).

In this study the BCC produced in presence of $B . s u b$ tilis were constituted manly by calcite. We demonstrated that the quality of this biogenic calcite was only influenced by calcium-carbon source. In that sense, the best composites were obtained when bacteria were grown in supplemented medium by glucose and calcium chloride. Finally, this non-coupled calcium-carbon condition promotes several nucleation sites for $\mathrm{CaCO}_{3}$ precipitation, and it was no need to provide with urea to achieve the necessary alkalinity.

\section{Supplementary information}

Supplementary information accompanies this paper at https://doi. org/10.1186/s13568-020-01111-6.

Additional file 1. Supplementary material.

\section{Abbreviations}

B. subtilis: Bacillus subtilis; BCC: Biogenic carbonate crystals; GLY: Glycerol $+\mathrm{CaCl}_{2} ; \mathrm{GLC}$ : Glucose $+\mathrm{CaCl}_{2} ; \mathrm{LAC}$ : Calcium lactate; ACE: Calcium acetate; OM: Organic matter; ACC: Amorphous calcium carbon; CBM: Controlled biological mineralization; INDBM: Induced biological mineralization; INFBM: Influenced biological mineralization; EPS: Extracellular polymeric substances; SEM: Scanning electron microscopy; EDX: Energy dispersive X-ray spectroscopy; XRD: X-ray diffraction; Cl: Crystallinity index; ATR-FTIR: Fourier transformed infra-red spectrometry; TGA: Thermogravimetric; DSC: Differentia scanning calorimetry.

\section{Acknowledgements}

This work represents part of Héctor Ferral-Pérez's PhD thesis done in "Programa de Doctorado en Ciencias Químico Biológicas" at UACJ with a scholarship grant of CONACyT. We acknowledge to Eng. Montserrat Hernández Ramírez from "Laboratorio de Geología", IIT-UACJ. for her advice in petographyc techniques; to M. C. Hortencia Reyes Blas from "Laboratorio de Microscopía Avanzada" and Tech. Ivan Salcido from "Centro de Investigación en Ciencia y Tecnología Aplicada", IIT-UACJ for SEM thechnical assistant; to M. C. Lorena Herrera from "Instituto de Ingeniería y Tecnología" at UACJ, for XRD technical assistant; to M. C. Marco Antonio Leiva, from Cinvestav-IPN, for Match software training; to PhD. Erasto Armando Zaragoza Contreras from Termic Analysis Laboratory at "Centro de Investigación en Materiales Avanzados" (CIMAV, Chihuahua), for TGA and DCC analysis. FTIR equipment was kindly lended by PhD. Yobani Reyes López from "Laboratorio de Materiales Híbridos Nanoestructurados", ICB-UACJ.

\section{Authors' contributions}

Planning and designing of this study: MAR; performing the experiments: HFP; performing the data analysis: HFP, MAR, BAT, AIP and MGG; manuscript drafting: HFP, MAR, MGG, BAT and AIP. All authors read and approved the final manuscript

\section{Funding}

This research was financially supported by Universidad Autónoma de Ciudad Juárez. 


\section{Availability of data and materials}

All relevant data are within the manuscript and its Additional file 1.

\section{Ethics approval and consent to participate}

Not applicable.

\section{Consent for publication}

Not applicable.

\section{Competing interests}

The authors declare that they have no competing interests.

\section{Author details}

${ }^{1}$ Laboratorio de Biología Celular y Molecular, Departamento de Ciencias Químico-Biológicas, Instituto de Ciencias Biomédicas, Universidad Autónoma de Ciudad Juárez, 32310 Cd. Juárez, CHIH, Mexico. ${ }^{2}$ Laboratorio de Electroquímica, Departamento de Ciencias Químico-Biológicas, Instituto de Ciencias Biomédicas, Universidad Autónoma de Ciudad Juárez, 32310 Cd. Juárez, CHIH, Mexico. ${ }^{3}$ Laboratorio de Bioquímica Funcional y Proteómica del Estrés, Departamento de Ciencias Químico-Biológicas, Instituto de Ciencias Biomédicas, Universidad Autónoma de Ciudad Juárez, 32310 Cd. Juárez, CHIH, Mexico. ${ }^{4}$ Laboratorio de Geología, Departamento de Ingeniería Civil y Ambiental, Instituto de Ingeniería y Tecnología, Universidad Autónoma de Ciudad Juárez, Cd. Juárez, $\mathrm{CHIH}$, Mexico.

Received: 5 September 2020 Accepted: 15 September 2020 Published online: 29 September 2020

\section{References}

Aizenberg J, Hendler G (2004) Designing efficient microlens arrays: lessons from Nature. J Mater Chem 14:2066

Aizenberg J, Lambert G, Weiner S, Addadi L (2002) Factor involved in the formation of amorphous and crystalline calcium carbonate: a study of an ascidian skeleton. J Am Chem Soc 124:32-39

Al Omari M, Rashid I, Qinna N, Badwan AA (2016) Calcium carbonate. In: Brittain HG (ed) Profiles of drug substances, excipients and related methodology. Academic press, Burlington, pp 31-132

Andrei AS, Pausan MR, Tamas T, Har N, Barbu-Tudoran L, Leopold N, Banciu HL (2017) Diversity and biomineralization potential of the epilithic bacterial communities inhabiting the oldest public stone monument of ClujNapoca (Transylvania, Romania). Front Microbiol 8:1-13

Arias J, Fernández M (2008) Polysaccharides and proteoglycans in calcium carbonate-based biomineralization. Chem Rev 108:4472-4482

Arnaouteli S, Matoz-Fernandez DA, Porter M, Kalamara M, Abbott J, MacPhee CE, Davidson FA, Stanley-Wall NR (2019) Pulcherrimin formation controls growth arrest of the Bacillus subtilis biofilm. Proc Natl Acad Sci USA 116:13553-13562

Azulay DN, Chai L (2019) Calcium carbonate formation in the presence of biopolymeric additives. J Vis Exp 147:e59638

Banks ED, Taylor NM, Gulley J, Lubbers BR, Giarrizo JG, Bullen HA, Hoehler TM, Barton HA (2010) Bacterial calcium carbonate precipitation in cave environments: a function of calcium homeostasis. Geomicrobiol J 27:444-454

Barabesi C, Galizzi A, Mastromei G, Rossi M, Tamburini E, Perito B (2007) Bacillus subtilis gene cluster involved in calcium carbonate biomineralization. J Bacteriol 189:228-235

Bhattacharya S, Baidya AK, Pal RR, Mamou G, Gatt YE, Margalit H, Rosenshine I, Ben-Yehuda S (2019) A ubiquitous platform for bacterial nanotube biogenesis. Cell Rep 27:334-342

Bots P, Benning L, Rodriguez-Blanco J, Roncal-Herrero T, Shaw S (2012) Mechanistic insights into the crystallization of amorphous calcium carbonate (ACC). Cryst Growth Des 12:3806-3814

Cantaert B, Kuo D, Matsumura S, Nishimura T, Sakamoto T, Kato T (2016) Use of amorphous calcium carbonate for the design of new materials. ChemPlu sChem 82:107-120

Ciferri O, Tiano P, Mastromei G (2000) Of microbes on art. The role of microbial communities in the degradation and protection of cultural heritage. Springer US, Boston

De Vrij W, Bulthuis R, Postma E, Konings WN (1985) Calcium transport in membrane vesicles of Bacillus subtilis. J Bacteriol 164:1294-1300
Decho AW (2010) Overview of biopolymer-induced mineralization: What goes on in biofilms? Ecol Eng 36:137-144

Dervaux J, Magniez JC, Libchaber A (2014) On growth and form of Bacillus subtilis biofilms. Interface Focus 4:20130051

Dhami NK, Reddy MS, Mukherjee A (2013) Biomineralization of calcium carbonates and their engineered applications: a review. Front Microbiol 4:19-25

Dhami NK, Reddy MS, Mukherjee A (2014) Synergistic role of bacterial urease and carbonic anhydrase in carbonate mineralization. Appl Biochem Biotechnol 172:2552-2561

Dove PM, Weiner S, De Yoreo JJ (2003) Biomineralization. Mineralogical Society of America Geochemical Society, Washington, D. C.

Dupraz C, Reid RP, Braissant O, Decho AW, Norman RS, Visscher PT (2009) Processes of carbonate precipitation in modern microbial mats. Earth Sci Rev 96:141-162

Ercole C, Cacchio P, Botta AL, Centi V, Lepidi A (2007) Bacterially induced mineralization of calcium carbonate: the role of exopolysaccharides and capsular polysaccharides. Microsc Microanal 13:42-50

Folk R, Lynch F (1997) The possible role of nanobacteria (Dwarf bacteria) in clay-mineral diagenesis and the importance of careful sample preparation in high-magnification SEM study. J Sediment Res 67:583-589

Frankel RB, Bazylinski DA (2003) Biologically induced mineralization by bacteria. Rev Miner Geochem 54:95-114

Han Z, Wang J, Zhao H, Tucker M, Zhao Y, Wu G, Zhou J, Yin J, Zhang H, Zhang $X$, Yan H (2019) Mechanism of biomineralization induced by Bacillus subtilis $\mathrm{J} 2$ and characteristics of the biominerals. Minerals 9(218):1-25

Humbert F, Quilès F (2011) In-situ study of early stages of biofilm formation under different environmental stresses by ATR-FTIR spectroscopy. In: Mendes-Vilas A (ed) Science against microbial pathogens: communicating current research and technological advances, 1st edn. Formatex Research Center, Badajoz, pp 889-895

Huynh NNT, Hung PV, Sangadji S, Son NK (2018) Identify the microbial-induced calcium carbonate precipitation in seawater environment and autogenous healing of microbial-modified mortar. SEATUC Symp 11:1-5

Jiménez-Delgadillo R, Valdés-Rodríguez SE, Olalde-Portugal V (2018) Effect of $\mathrm{pH}$ and temperature on the growth and antagonistic activity of Bacillus subtilis on Rizoctonia solani. Rev Mex Fis 36:256-275

Knorre HV, Krumbein WE (2000) Bacterial Calcification. Microbial Sediments. Springer, Berlin Heidelberg, pp 25-31

Kontoyannis CG, Vagenas NV (2000) Calcium carbonate phase analysis using XRD and FT-Raman spectroscopy. Analyst 125:251-255

Li XG, Lv Y, Ma BG, Wang WQ, Jian SW (2017) Decomposition kinetic characteristics of calcium carbonate containing organic acids by TGA. Arabian J Chem 10:S2534-S2538

López-Moreno A, Sepúlveda-Sánchez JD, Alonso Guzmán EM, Le Borgne S (2014) Calcium carbonate precipitation by heterotrophic bacteria isolated from biofilms formed on deteriorated ignimbrite stones: influence of calcium on EPS production and biofilm formation by these isolates. Biofouling 30:547-560

Marvasi M, Gallagher KL, Martinez LC, Molina Pagan WC, Rodríguez Santiago RE, Castilloveitía Vega G, Visscher PT (2012) Importance of B4 medium in determining organomineralization potential of bacterial environmental isolates. Geomicrobiol J 29:916-924

Marvasi M, Casillas-Santiago LM, Henríquez T, Casillas-Martinez L (2017) Involvement of etfA gene during $\mathrm{CaCO}_{3}$ precipitation in Bacillus subtilis biofilm. Geomicrobiol J 34:722-728

Meier A, Kastner A, Harries D, Wierzbicka-Wieczorek M, Majzlan J, Büchel G, Kothe E (2017) Calcium carbonates: induced biomineralization with controlled macromorphology. Biogeosciences 14:4867-4878

Merino L, Morales J (2008) Relationship of the cristallinity index $(\mathrm{Cl})$ with the age and content of $\mathrm{Fe}$ and $\mathrm{CO}_{3}$ ions in vertebrate fossil samples. Estud Geol 64:75-87

Micallef R, Vella D, Sinagra E, Zammit G (2016) Biocalcifying Bacillus subtilis cells effectively consolidate deteriorated Globigerina limestone. J Ind Microbiol Biotechnol 43:941-952

Murphy CP (1986) Thin section preparation of soils and sediments. A.B. Academic, Berkhamsted

Ngwenya BT (2016) Bacterial mineralization. In: Reference module in materials science and materials engineering. Elsevier

Oppenheimer-Shaanan Y, Sibony-Nevo O, Bloom-Ackermann Z, Suissa R, Steinberg N, Kartvelishvily E, Brumfeld V, Kolodkin-Gal I (2016) Spatio-temporal 
assembly of functional mineral scaffolds within microbial biofilms. NPJ Biofilms Microbiomes 2:15031

Páramo LA, Narváez JA, Ortega-Morales BO (2015) La bioprecipitación de carbonato de calcio por la biota nativa como un método de restauración. Nexo Rev Cient 28:25-40

Patterson A (1939) The Scherrer formula for X-ray particle size determination. Phys Rev 56:978-982

Peng N, Cai P, Mortimer M, Wu Y, Gao C, Huang Q (2020) The exopolysaccharide-eDNA interaction modulates 3D architecture of Bacillus subtilis biofilm. BMC Microbiol 20:115

Perito B, Mastromei G (2011) Molecular basis of bacterial calcium carbonate precipitation. Prog Mol Subcell Biol 52:113-139

Perito B, Biagiotti L, Daly S, Galizzi A, Tiano P, Mastromei G, Ciferri O, Editor, G Mastromei PT, O. Ciferri and G Mastromei PT (2000) Bacterial genes involved in calcite crystal precipitation. Microbes Art role Microb communities Degrad Prot Cult Herit, pp 219-230

Perito B, Marvasi M, Barabesi C, Mastromei G, Bracci S, Vendrell M, Tiano P (2014) A Bacillus subtilis cell fraction (BCF) inducing calcium carbonate precipitation: biotechnological perspectives for monumental stone reinforcement. J Cult Herit 15:345-351

Perri E, Spadafora A (2011) Evidence of microbial biomineralization in modern and ancient stromatolites. In: Tewari V, Seckbach J (eds) Stromatolites: interaction of microbes with sediments, 1st edn. Springer, Berlin

Person A, Bocherens H, Saliège J-F, Paris F, Zeitoun V, Gérard M (1995) Early diagenetic evolution of bone phosphate: an X-ray diffractometry analysis. J Archaeol Sci 22:211-221

Plav B, Kobe S, Orel B (1999) Identification of crystallization forms of $\mathrm{CaCO}_{3}$ with FTIR spectroscopy. Kovine Zlitine Tehnol 33:517-521

Pokroy B, Fitch A, Marin F, Kapon M, Adir N, Zolotoyabko E (2006) Anisotropic lattice distortions in biogenic calcite induced by intra-crystalline organic molecules. J Struct Biol 155:96-103

Priya JN, Kannan M, Priyanka P, Mary SV (2016) A study on characterization of EPS and media optimization for bacterial calcium carbonate precipitation. Int J Curr Microbiol Appl Sci 5:590-595

Rasmussen B, Muhling JR (2019) Organic-rich microfossils produced by oil infiltration of hollow silicified bacteria: evidence from the ca. $340 \mathrm{Ma}$ Red Dog Zn-Pb deposit, Alaska. Geology 47:1107-1111

Reeksting BJ, Hoffmann TD, Tan L, Paine K, Gebhard S (2020) In-depth profiling of calcite precipitation by environmental bacteria reveals fundamental mechanistic differences with relevance to application. Appl Environ Microbiol 86:e02739-e03019

Robinson TP, Wimpenny JWT, Earnshaw RG (1991) pH gradients through colonies of Bacillus cereus and the surrounding agar. J Gen Microbiol 137:2885-2889

Rodriguez-Navarro C, Jimenez-Lopez C, Rodriguez-Navarro A, Gonzalez-Muñoz MT, Rodriguez-Gallego M (2007) Bacterially mediated mineralization of vaterite. Geochim Cosmochim Acta 71:1197-1213

Rusznyák A, Akob D, Nietzsche S, Eusterhues K, Totsche KW, Neu TR, Frosch T, Popp J, Keiner R, Geletneky J, Katzschmann L, Schulze ED, Küse K (2012) Calcite biomineralization by bacterial isolates from the recently discovered Pristine Karstic Herrenberg Cave. Appl Environ Microbiol 78:1157-1167

Saier MH Jr, Goldman SR, Maile RR, Moreno MS, Weyler W, Yang N, Paulsen IT (2002) Transport capabilities encoded within the Bacillus subtilis genome. J Mol Microbiol Biotechnol 4:37-67

Schmitt J, Flemming H-C (1998) FTIR-spectroscopy in microbial and material analysis. Int Biodeterior Biodegrad 41:1-11

Seifan M, Samani A, Berenjian A (2016) Induced calcium carbonate precipitation using Bacillus species. Appl Microbiol Biotechnol 100:9895-9906

Shirakawa MA, Cincotto MA, Atencio D, Gaylarde CC, John VM (2011) Effect of culture medium on biocalcification by Pseudomonas putida, Lysinibacillus sphaericus and Bacillus subtilis. Braz J Microbiol 42:499-507

Sierra-Beltran MG, Jonkers HM, Schlangen E (2014) Characterization of sustainable bio-based mortar for concrete repair. Constr Build Mater 67:344-352

Stumm W (1990) Aquatic chemical kinetics: reactions rates in natural waters. 1 st ed

Weiner S, Levi-Kalisman Y, Raz S, Addadi L (2003) Biologically formed amorphous calcium carbonate. Connect Tissue Res 44:214-218

Zhuang D, Yan H, Tucker ME, Zhao H, Han Z, Zhao Y, Suna B, Lia D, Panb J, Zhaoa Y, Menga R, Shanb G, Zhanga X, Tang R (2018) Calcite precipitation induced by Bacillus cereus MRR2 cultured at different $\mathrm{Ca}^{2+}$ concentrations: further insights into biotic and abiotic calcite. Chem Geol 500:64-87

\section{Publisher's Note}

Springer Nature remains neutral with regard to jurisdictional claims in published maps and institutional affiliations.

\section{Submit your manuscript to a SpringerOpen ${ }^{\circ}$ journal and benefit from:}

- Convenient online submission

- Rigorous peer review

- Open access: articles freely available online

- High visibility within the field

- Retaining the copyright to your article

Submit your next manuscript at $\boldsymbol{\nabla}$ springeropen.com 